\title{
Climatic impact of Arctic Ocean methane hydrate dissociation in the $21^{\text {st }}$-century
}

Sunil Vadakkepuliyambatta ${ }^{1 *}$, Ragnhild B Skeie ${ }^{2}$, Gunnar Myhre², Stig B Dalsøren², Anna Silyakova $^{1}$, Norbert Schmidbauer ${ }^{3}$, Cathrine Lund Myhre ${ }^{3}$, Jürgen Mienert ${ }^{1}$

${ }^{1}$ CAGE-Center for Arctic Gas Hydrate, Environment, and Climate, Department of Geosciences, UiT-The Arctic University of Norway, 9037 Troms $\emptyset$, Norway.

${ }^{2}$ CICERO-Center for International Climate and Environmental Research - Oslo, PB. 1129 Blindern, 0318 Oslo, Norway.

${ }^{3}$ NILU - Norwegian Institute for Air Research, Instituttveien 18, 2027 Kjeller, Norway.

\section{Abstract}

2 Greenhouse gas methane trapped in sub-seafloor gas hydrates may play an important role in a 3 potential climate feedback system. The impact of future Arctic Ocean warming on the hydrate stability and its contribution to atmospheric methane concentrations remains an important and unanswered question. Here, we estimate the climate impact of released methane from oceanic gas hydrates in the Arctic to the atmosphere towards the end of the $21^{\text {st }}$ century, integrating hydrate stability and atmospheric modeling. Based on future climate models, we estimate that increasing ocean temperatures over the next 100 years could release up to $17 \pm 6 \mathrm{Gt} \mathrm{C}$ into the Arctic Ocean. However, the released methane has a limited or minor impact on the global mean surface temperature, contributing only $0.1 \%$ of the projected anthropogenic influenced warming over the $21^{\text {st }}$ century.

\section{Introduction}

Methane is a greenhouse gas, which has a global warming potential $~ 28$ times greater than $\mathrm{CO}_{2}$ over 100 years (Myhre et al., 2013). The gas contributes significantly to the recent increase in global temperature and increasing atmospheric greenhouse gas levels (Hartmann et al., 2013;Saunois et al., 2016). A large amount of methane in the ocean is trapped in sediments in the form of gas hydrates, an ice-like crystalline substance made of water and gas (Sloan and Koh, 2008), which occurs in the pore space of sediments in continental margins all 
Earth Syst. Dynam. Discuss., https://doi.org/10.5194/esd-2017-110

Manuscript under review for journal Earth Syst. Dynam.

Discussion started: 18 December 2017

(c) Author(s) 2017. CC BY 4.0 License.

over the world (Collett et al., 2009). Gas hydrates are generally stable under high-pressure and low-temperature but are extremely sensitive to slight variations in these conditions. The release of methane from dissociating hydrates in response to a warming ocean has been suggested to have major implications for past and rapid warming events (Dickens et al., 1997) resulting in a positive climate feedback (Berbesi et al., 2014;Kroeger and Funnell, 2012). The potential impact of hydrates on global climate and its consideration as an unconventional energy resource lead to numerous studies trying to estimate the amount of methane trapped in hydrates beneath the ocean floor (Archer et al., 2009;Buffett and Archer, 2004;Burwicz et al., 2011;Dobrynin et al., 1981;Kretschmer et al., 2015;Kvenvolden, 1988;Milkov, 2004).

Furthermore, there is a concern that ongoing global warming could result in the dissociation of $\sim 2 \%$ of the existing global sub-sea hydrates over the next 800 years (Hunter et al., 2013). However, the fate of the released methane and its impact on the atmosphere and climate remains very uncertain and a quantitative assessment is therefore deemed important for climate projections.

In particular, the Arctic environment is a very climatically sensitive region, which is warming fast and twice as much than the rest of the world. This phenomenon is called the Arctic amplification (Screen and Simmonds, 2010). Under the RCP8.5 "business as usual" scenario (Stocker et al., 2013), the Arctic temperature could rise as much as 10-12 degrees by 2100 in certain areas. The Arctic Ocean hosts numerous methane seeps that are presently very active and gas hydrate accumulations that are widespread but with a patchy distribution (Bünz et al., 2012;Paull et al., 2007;Ruppel, 2015;Phrampus et al., 2014;Shakhova et al., 2010;Sahling et al., 2014). Some of the methane seeps are directly connected with dissociating methane hydrates (Westbrook et al., 2009;Berndt et al., 2014;Portnov et al., 2016) and/or thawing subsea permafrost (Portnov et al., 2013) after ice sheet retreats. Although the suggested gas hydrate storage in the Arctic represents only a fraction of the global repository of methane 
Earth Syst. Dynam. Discuss., https://doi.org/10.5194/esd-2017-110

Manuscript under review for journal Earth Syst. Dynam.

Discussion started: 18 December 2017

(c) Author(s) 2017. CC BY 4.0 License.

stored in hydrates (Kretschmer et al., 2015;Marín-Moreno et al., 2016), the rapid loss of sea ice (Boe et al., 2009), thawing subsea permafrost, and a warming ocean (Ferré et al., 2012) could potentially result in accelerated release of methane from dissociating hydrates. This study presents a quantitative analysis of the impact of methane hydrate dissociation on the atmosphere and climate over the $21^{\text {st }}$ century. To this end, we analyze methane hydrate dissociation in the Arctic Ocean and potential methane emissions to the atmosphere due to ocean warming. The approach utilizes an ensemble of nine Coupled Model Intercomparison Project (CMIP5) (Taylor et al., 2012) climate predictions to model the transient evolution of hydrate stability with variations in ocean bottom water temperature. The impact of methane emissions resulting from gas hydrate dissociation on the atmosphere is then analyzed through atmospheric chemistry and transport modeling. Finally, we calculate the radiative forcing of the atmospheric perturbation resulting from the release of methane from hydrate dissociation over the next 100 years.

\section{Methods}

\subsection{Quantification of the present-day methane hydrate reservoir in the Arctic}

The amount of methane trapped as gas hydrates is calculated based on the thickness of methane hydrate stability zone, hydrate saturation in the sediments, and the porosity. Methane hydrate stability thickness in the Arctic sediments north of $65^{\circ} \mathrm{N}$ is estimated using the CSMHYD program (Sloan and Koh, 2008) for pure methane gas and a pore-water salinity of $35 \%$. The input data for the hydrate stability modeling include the IBCAO bathymetry (Jakobsson et al., 2012) and thermal gradient measurements over the Arctic (Bugge et al., 2002;Phrampus et al., 2014;Damm et al., 2013;Pollack et al., 1993) (See S1 for more details).

Estimation of hydrate saturation in the sediment pore space involves direct methods such as drilling or indirect methods which involve analysis of seismic data. As there are no direct 
Earth Syst. Dynam. Discuss., https://doi.org/10.5194/esd-2017-110

Manuscript under review for journal Earth Syst. Dynam.

Discussion started: 18 December 2017

(c) Author(s) 2017. CC BY 4.0 License.

measurements of hydrate saturation in the Arctic Ocean, we adopt hydrate saturation estimates derived from analysis of ocean-bottom seismic data from offshore Svalbard (Hustoft et al., 2009;Chabert et al., 2011;Westbrook et al., 2008). Based on these studies, we apply a constant hydrate saturation of $9 \pm 3 \%$ of pore space throughout the gas hydrate stability zone in the Arctic sediments. We assume a constant hydrate-free sulfate reduction zone extending from the seafloor to a depth of $5 \mathrm{~m}$ in the sediments (Riedel et al., 2006), where anaerobic oxidation consumes methane. The gas hydrate stability zone is adjusted based on the global sediment thickness map in areas where the base of hydrate stability zone exceed the thickness of sediments (Laske and Masters, 1997). We employ a porosity curve, with values from available ocean drilling data (for locations of the drill holes, see Fig. S3) (IODP database, http://iodp.tamu.edu/janusweb/links/links_all.shtml) for the estimation of available pore-space for hydrate formation. To estimate the volume of methane trapped in hydrates, we consider $163 \mathrm{~m}^{3}$ of methane trapped in $1 \mathrm{~m}^{3}$ of hydrates with a $94 \%$ cage occupancy based on observations from Blake Ridge (Lorenson and Collett, 2000). The number of moles of methane estimated stems from the methane volume using the ideal gas law at STP.

\subsection{Transient evolution of methane hydrate reservoir}

To estimate the evolution of methane hydrate stability in the Arctic during the $21^{\text {st }}$ century (2006-2100), we consider seafloor temperature variations from nine different CMIP5 climate models (Arora et al., 2011; von Salzen et al., 2013;Gent et al., 2011;Hurrell et al., 2013;Dunne et al., 2012;Dunne et al., 2013;Schmidt et al., 2006;Schmidt et al., 2014;Collins et al., 2011;Martin et al., 2011;Dufresne et al., 2013;Watanabe et al., 2011;Jungclaus et al., 2013; Stevens et al., 2013) (Table S1) based on the RCP 8.5 scenario (Riahi et al., 2011). Using an ensemble of models illustrates the uncertainty range in model simulations and the multi-model mean generally agrees more favorably with observations than the individual models (Flato et al., 2013). It also increases the robustness of results and estimates for the $21^{\text {st }}$ 
Earth Syst. Dynam. Discuss., https://doi.org/10.5194/esd-2017-110

Manuscript under review for journal Earth Syst. Dynam.

Discussion started: 18 December 2017

(c) Author(s) 2017. CC BY 4.0 License.

century. The climate models have a temporal resolution of one year which allows analysis of hydrate stability evolution at a high temporal resolution. A 3D finite-difference heat flow model is used to estimate the diffusive transport of seafloor temperature variation through the sediments (Turcotte and Schubert, 2002;Spiegelman, 2004;Gerya, 2010;Phrampus and Hornbach, 2012) (see S4 for more details). Afterwards, the resulting subsurface temperature profile for each year allows estimating the thickness of the methane hydrate stability zone and the methane stored within the zone as hydrates.

\subsection{Radiative forcing of released methane from methane hydrates}

The estimated yearly average methane emissions to the atmosphere from methane hydrate dissociation as predicted by the transient hydrate model were added as an additional emission source in a simulation using the Oslo CTM3 model (Dalsøren et al., 2016;Søvde et al., 2012). The lifetime of methane is longer than the time-scale for interhemispheric exchange, it is therefore not critical for the climate impact study to know exactly where the extra Arctic Ocean gas emissions occur. Emissions are therefore distributed evenly over the ocean north of $70^{\circ} \mathrm{N}$. The initialization of the atmosphere started with the year 2006 concentrations of methane and other chemical compounds affecting the atmospheric chemistry as described in Dalsøren et al. (2016). See also Dalsøren et al. (2016) for further details on model setup, chemical reactions, and applied meteorological fields. The model was then run with the extra methane flux until the atmospheric methane burden reached a new equilibrium. The calculated change in tropospheric methane concentration was used to quantify the radiative forcing using simplified equations for methane (Myhre et al., 1998). 
Earth Syst. Dynam. Discuss., https://doi.org/10.5194/esd-2017-110

Manuscript under review for journal Earth Syst. Dynam.

Discussion started: 18 December 2017

(c) Author(s) 2017. CC BY 4.0 License.

\section{Results and Discussion}

\subsection{Methane hydrates in the Arctic and its response to a warming ocean}

The present-day hydrate stability zone in the Arctic modeled using present-day pressuretemperature conditions is shown in figure 1. On the continental shelves off northern Norway, Svalbard, Russia, and Alaska, the pressure-temperature conditions are not suitable for the widespread occurrence of methane hydrate accumulations, except for relatively smaller areas in the Barents Sea. Gas hydrates could be stable under the submarine permafrost off the coast of Russia and Alaska. Permafrost conditions are not considered in this model, however, the hydrate accumulations are relatively small in the marine permafrost regions (Ruppel, 2015). Even today, the depth of the hydrate stability zone may reach a substantial $700 \mathrm{~m}$ thickness beneath the seafloor (dark blue) as seen in the Canada Basin, where water depths reach approx. $4000 \mathrm{~m}$ (Fig.1).

Based on the thickness of the modeled gas hydrate stability zone and hydrate saturation within the sediments we estimate a methane hydrate volume of $29 \pm 12(1-\sigma)$ trillion $\mathrm{m}^{3}$, which is equivalent to $4777 \pm 1901(1-\sigma)$ trillion $\mathrm{m}^{3}$ of methane or $2524 \pm 1005(1-\sigma)$ Gt of carbon. The model does not include hydrates trapped under submarine permafrost on Arctic continental shelves, which may amount to approx. 20 Gt of carbon (Ruppel, 2015). Our estimate falls within the range of values reported previously, with its lowest at $110 \mathrm{Gt}$ of carbon (Kretschmer et al., 2015) and highest at $9000 \mathrm{Gt}$ of carbon (Biastoch et al., 2011).

The impact of non-linear variations in the ocean bottom temperature on methane hydrate stability during the $21^{\text {st }}$ century is evaluated by employing an ensemble of nine CMIP5 climate models (from 2006-2100) under the RCP8.5 scenario (Fig.2a). The model data were compared to measured bottom water temperatures for the period 1960-2013 at three different locations (Fig.2a). More than half of the selected climate models agree well with the observed 
Earth Syst. Dynam. Discuss., https://doi.org/10.5194/esd-2017-110

Manuscript under review for journal Earth Syst. Dynam.

Discussion started: 18 December 2017

(c) Author(s) 2017. CC BY 4.0 License.

bottom water temperature, except in the Beaufort Shelf, but there the number of measurements is relatively low. The values predicted by the model are yearly averages hence the mismatch between seasonal measurements and model predictions are expected. The climate models reveal bottom water temperatures variations up to $11{ }^{\circ} \mathrm{C}$ (e.g., HadGEM2-ES) in the Barents Sea over the 94 years from 2006-2100 (Fig.2a). The lowest variation in bottom water temperature over this period (an increase of $<1{ }^{0} \mathrm{C}$ ) is projected by the GISS-E2-R model.

In the model, the thickness of the hydrate stability zone varies in response to the changes in bottom water temperature. Due to the non-linearity of bottom water temperature variations, shallow hydrates may form or dissociate if the bottom water gets colder or warmer, respectively. However, since the bottom water temperature increases overall over the investigated period, the total volume of methane hydrates in the Arctic is lower in the year 2100 than 2006 . We estimate $\sim 0.7 \% \pm 0.25(1-\sigma)$ of the initial hydrate volume could dissociate until 2100 (Fig. 2b). This corresponds to $32.48 \pm 11.6(1-\sigma)$ trillion $\mathrm{m}^{3}$ (22884 \pm $8173 \mathrm{Tg}$ ) of methane or $17.15 \pm 6.13(1-\sigma)$ Gt of carbon that could be released into the water column of the Arctic over the course of 94 years, until the year 2100. The amount of methane dissociated from hydrates varies from year to year with a maximum of $428 \pm 217 \mathrm{Tg} \mathrm{yr}^{-1} \mathrm{of}$ methane during the year 2081 (Fig.3). These variations are mainly due to the fluctuations in ocean bottom temperatures (Fig.2a) resulting in a rapid response of the shallow hydrate system, typically 1-50 m below the seafloor.

Our calculations show a mean value of $220 \pm 160 \mathrm{Tg} \mathrm{yr}^{-1}$ of methane released from hydrate dissociation at the Arctic seabed to the ocean. In our estimate, we assume no heat changes during hydrate dissociation or gas retention in sediments, and no delay in the time taken for the gas to migrate through the sediments to the seafloor. These effects may slow-down methane flux to the water column in the short term (100 years) by up to $>70 \%$ (Stranne et al., 
Earth Syst. Dynam. Discuss., https://doi.org/10.5194/esd-2017-110

Manuscript under review for journal Earth Syst. Dynam.

Discussion started: 18 December 2017

(c) Author(s) 2017. CC BY 4.0 License.

2016b), hence we present an upper estimate. Biastoch et al. (2011) predicted a mean emission of $162 \mathrm{Tg} \mathrm{yr}^{-1}$ of methane release from the Arctic seabed. A more recent study using a single climate model predicted a reduction of up to $0.12 \%$ of the existing gas hydrate reservoir by the end of the century (Kretschmer et al., 2015). Both these results are of the same order of magnitude as our estimations.

The distribution of the methane releases from methane hydrates to the ocean until 2100 are not uniform in the Arctic (Fig.4a). The Arctic continental slopes are hotspots for hydrate dissociation due to ocean warming. The area affected most is the SW Barents Sea, where up

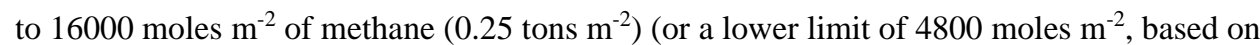
Stranne et al. (2016b)) could be released into the water column before 2100 (Fig.4a). Most of the hydrate dissociation occurs in the 350-450 m seafloor depth range. Reported methane seeps from Arctic regions (Fig.4a, red dots), generally match predicted locations of hydrate dissociation, except in permafrost areas which are not considered in our model. From very active methane seep areas on the West Svalbard margin, a methane bubble flow of 4-50 x $10^{6}$ mol $\mathrm{yr}^{-1}$ is reported at a water depth of around 380-390 $\mathrm{m}$ using a bubble catcher during the year 2012 (Sahling et al., 2014). This is at least an order of magnitude lower than our mean estimate of $384 \times 10^{6} \mathrm{~mol} \mathrm{yr}^{-1}$. Modeling conducted over the same area (Marín-Moreno et al., 2015) estimate a methane flow from the seabed (420-450 m water depth) of about 25-35 mol $\mathrm{yr}^{-1} \mathrm{~m}^{-2}$ from dissociating hydrates. It is comparable to our mean estimate of about $27 \mathrm{~mol} \mathrm{yr}^{-1}$ $\mathrm{m}^{-2}$ at that location. These estimates are close to methane bubble emissions from thawing subsea permafrost in the East Siberian Shelf (Shakhova et al., 2014). 
Earth Syst. Dynam. Discuss., https://doi.org/10.5194/esd-2017-110

Manuscript under review for journal Earth Syst. Dynam.

Discussion started: 18 December 2017

(c) Author(s) 2017. CC BY 4.0 License.

\subsection{Methane release from the Arctic Ocean and its potential impact on the atmosphere and} climate

The migration of methane from the seabed to the surface water can be either through bubbles or as dissolved methane. Modeling studies suggest that for water depths more than $100 \mathrm{~m}$, methane gas bubbles may not be able to reach the surface water (McGinnis et al., 2006). In addition, methane gas can diffuse out of bubbles, so that most of the methane gas dissolves within the water column before reaching the surface (McGinnis et al., 2006). Various microbial processes and oceanic conditions control the fate of dissolved methane in the water column (AMAPAssessment, 2015). Aerobic microbial oxidation can consume dissolved methane in the water column, the rate of which depends on the amount of methane available and hydrodynamic conditions (Valentine et al., 2001). In addition, water mass stratification is a potential barrier for upward migration of dissolved methane (Graves et al., 2015;Geprägs et al., 2016;Steinle et al., 2015). Recent studies from Western Svalbard identified efficient methane filtering by oxidation and water mass stratification in the water column (Graves et al., 2015; Steinle et al., 2015), and very little to no methane flux into the atmosphere from waters offshore western Svalbard during the 2015 summer season despite high concentrations of methane above the seabed (Myhre et al., 2016).

Nevertheless, methane released at seabed could still reach the surface waters under favorable oceanographic conditions as stormy seas, and winter time, and in shallow seas $(<50 \mathrm{~m})$ (Shakhova et al., 2014). Analysis of water column methane concentration measurements from the Arctic (Table S2) show that the amount of methane that reaches surface waters is a function of the water depth (Fig.4b) (Mau et al., 2015;Shakhova et al., 2010;Schneider von Deimling et al., 2011;Damm et al., 2008;Damm et al., 2007;Damm et al., 2005;Myhre et al., 2016;Gentz et al., 2014;Lammers et al., 1995;Steinle et al., 2015;Graves et al., 2015). More than $50 \%$ of the methane released at the seabed seem to reach the surface waters when the 
Earth Syst. Dynam. Discuss., https://doi.org/10.5194/esd-2017-110

Manuscript under review for journal Earth Syst. Dynam.

Discussion started: 18 December 2017

(c) Author(s) 2017. CC BY 4.0 License.

water depth is lower than $20 \mathrm{~m}$ (Fig. 4b, Table S2). However, the amount of methane that reaches the surface water reduce drastically as the water depth increases. Around the water depth of 300-400 m, where most of the hydrate dissociation areas are located (Fig. 4a), the amount of methane that reached surface water was between 0.1 and $7.5 \%$ of the amount released at the seabed (Fig. 4b, Table S2). The ocean surface water-atmosphere methane flux depends greatly on the wind conditions and the equilibrium concentration of methane in seawater (Shakhova et al., 2014;Graves et al., 2015). Offshore west Svalbard, sea wateratmosphere methane flux was up to $\sim 50 \%$ of the surface water concentration over two seasons (Graves et al., 2015). Based on this we propose that $1 \%(0.1$ to $10 \%)$ of the methane released at the seafloor reaching the atmosphere. This translates to an emission of $2.2 \mathrm{Tg} \mathrm{CH}_{4}$ $\mathrm{yr}^{-1}(0.2-22)$ to the atmosphere from hydrate dissociation in the Arctic. This is about five times lower than the anthropogenic methane emissions in the Arctic in the year 2005 from

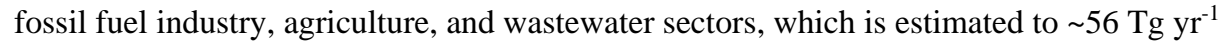
(ranging from $56-67$ as per three different agencies) of $\mathrm{CH}_{4}$ and predicted to increase up to $103 \mathrm{Tg} \mathrm{yr}^{-1}$ of $\mathrm{CH}_{4}$ by 2050 (based on GAINS CLE) (AMAPAssessment, 2015).

To assess the atmospheric changes and calculate the additional radiative forcing due to methane emissions from hydrates dissociation until 2100, we have added emissions of $2.2 \mathrm{Tg}$ $\mathrm{CH}_{4} \mathrm{yr}^{-1}(0.2-22)$ to a detailed global chemistry-transport model (Dalsøren et al., 2016) for calculations of the corresponding changes in the atmospheric $\mathrm{CH}_{4}$ concentration. The simulated global mean increase in atmospheric $\mathrm{CH}_{4}$ concentration over the period 2006-2100 is estimated to be $13 \mathrm{ppb}(1.3-130)$. We calculate a radiative forcing of $0.005 \mathrm{Wm}^{-2}(0.0005$ to 0.05) from this change in atmospheric methane abundance (Myhre et al., 1998). A change in atmospheric $\mathrm{CH}_{4}$ also changes ozone and stratospheric water vapor. Based on previous simulations, we quantify our upper limit to be less than $50 \%$ of the $\mathrm{CH}_{4}$ radiative forcing (Isaksen et al., 2011). The radiative forcing due to the release of methane from hydrate 
Earth Syst. Dynam. Discuss., https://doi.org/10.5194/esd-2017-110

Manuscript under review for journal Earth Syst. Dynam.

Discussion started: 18 December 2017

(c) Author(s) 2017. CC BY 4.0 License.

dissociation to the atmosphere is therefore estimated to be in an upper range of $0.007 \mathrm{Wm}^{-2}$ (0.0007 to 0.07 ) up till 2100 . To put such a change into perspective, this is less than $0.1 \%$ of the total radiative forcing in the RCP8.5 scenario. This conclusion holds even with a $25 \%$ increase in the radiative forcing of methane recently estimated, mainly due to the inclusion of shortwave absorption by methane (Etminan et al., 2016).

Our study suggests that even under strong global warming (RCP 8.5) projections, Arctic methane hydrate dissociation and fluxes to the atmosphere may have a negligible impact on the global climate and thus on a climate feedback loop in the near future (within this century). The added $13 \mathrm{ppb}$ of methane to the atmosphere from hydrate dissociation is comparable to the annual yearly increase in recent years (The global mean increase from 2014-2015 was 11 ppb (WMO, 2016)). To reach a 1-degree additional increase in global temperature, it would require three to four times increase in the methane concentration, i.e., on the order of $800 \mathrm{Tg}$ $\mathrm{yr}^{-1}$ of methane release from the Arctic Ocean to the atmosphere over the course of $21^{\text {st }}$ century (Isaksen et al., 2011; Samset et al., 2016). Based on our study, a maximum amount of only $380 \mathrm{Tg} \mathrm{yr}^{-1}$ of methane might release into the Arctic atmosphere due to hydrate dissociation, considering no ocean filter.

The contribution of marine methane seepage to the global methane emission is estimated to be $\sim 20 \mathrm{Tg} \mathrm{yr}^{-1}$ (Kvenvolden et al., 2001), with a global contribution of 2-10 $\mathrm{Tg} \mathrm{yr}^{-1}$ from hydrates (Ciais et al., 2013). Airborne observations of methane in the Arctic Ocean suggest a methane efflux of 10.2 $\mathrm{Tg} \mathrm{yr}^{-1}$ (Kort et al., 2012). These values, along with the reported emissions on the East Siberian Arctic Shelf (Shakhova et al., 2010), are within our estimated range of 0.2 -

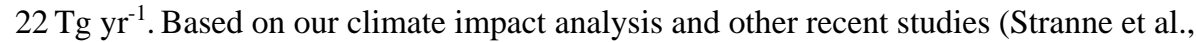
2016a;Ruppel and Kessler, 2017), gas hydrate dissociation in the Arctic Ocean appears to be a minor methane source to the atmosphere in the near future. 
Earth Syst. Dynam. Discuss., https://doi.org/10.5194/esd-2017-110

Manuscript under review for journal Earth Syst. Dynam.

Discussion started: 18 December 2017

(c) Author(s) 2017. CC BY 4.0 License.

\section{Impact of model uncertainties}

As with any modeling exercise analyzing a complex system, the modeling presented here also involve large uncertainties. Some of these uncertainties arise from the lack of data coverage, whereas a few are inherent due to the complex nature of the Earth system. The uncertainties that arise from the lack of data include heat flow data and sediment porosity. These parameters have a significant impact on the estimation of gas hydrate volume within the Arctic Ocean sediments as presented in the supplementary material (S2, fig. S5). As such, this manuscript is not an effort to improve on the methodology or the estimate of hydrate volume in the Arctic marine sediments. We utilize the volume of hydrates as a marker to evaluate potential scenarios of hydrate dissociation in the $21^{\text {st }}$ century and try to evaluate its impact on climate. The most significant parameters that have a larger impact are hydrate saturation and transport of methane through the sediments and water column.

The nature of hydrate distribution through the hydrate stability zone is almost impossible to estimate or model over large regions such as the Arctic Ocean. Hence, we have considered a constant hydrate saturation throughout the hydrate stability zone. This might inflate the gas hydrate volume within the sediments, and the estimates presented here should be taken as a first-order estimate. However, this does not necessarily affect our conclusion, as even with very high estimates of hydrate volume or methane release, the impact on the atmosphere remains minor.

As previously mentioned, our study does not account for methane release from permafrostdegradation in the Arctic shelves (e.g., Shakhova et al., 2017; Shakhova et al., 2015). Increasing ocean temperatures, seawater transgression, and seafloor erosion are contributing to rapid degradation of marine permafrost which could potentially release methane into shallow water column (Shakhova et al., 2017). Approximately $20 \mathrm{Gt}$ of carbon ( 26 Pg of 
Earth Syst. Dynam. Discuss., https://doi.org/10.5194/esd-2017-110

Manuscript under review for journal Earth Syst. Dynam.

Discussion started: 18 December 2017

(c) Author(s) 2017. CC BY 4.0 License.

$\mathrm{CH}_{4}$ ) might be trapped as methane under the thawing Arctic shelves ( $\left.<200 \mathrm{~m}\right)$ (Ruppel, 2015). Complete destabilization of permafrost generally takes $\sim 5-7 \mathrm{kyr}$, based on modeling results (Romanovskii et al., 2005). If we consider a rapid degradation of permafrost within a 1 kyr period (e.g., Shakhova et al., 2014), the maximum amount of methane that could be

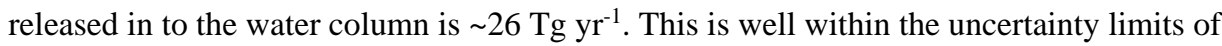
our estimated $220 \pm 160 \mathrm{Tg} \mathrm{yr}^{-1}$ emission from gas hydrate dissociation.

As detailed in sections 3.1 and 3.2, the transport of methane is slow through the sediments and methane is consumed both in the shallow sediments as well as within the water column. Methane oxidation in the water column can add to the $\mathrm{CO}_{2}$ budget of the Ocean. However, additional $\mathrm{CO}_{2}$ generated through this process is at least seven orders of magnitude lower than the $\mathrm{CO}_{2}$ influx into the Ocean (e.g., Takahashi et al., 2009;Mau et al., 2013) and has negligible impact on the earth system model used in this study. This is not accounted in our study, as the additional $\mathrm{CO} 2$ generaConsidering that most of the hydrate dissociation occur over water depths of 300-400 m, little to no methane might be reaching the atmosphere, as evidenced offshore Svalbard (Myhre et al., 2016). Thus, our model here might be overestimating the methane flux into the atmosphere, as well as its radiative forcing. However, this also does not affect our conclusions as our estimates show that even if the effect of the water column is neglected, the methane flux to the atmosphere is too low to have a significant impact on global temperatures.

\section{Conclusions}

Here we present the climate impact of methane emissions from dissociating gas hydrates over the Arctic Ocean in the $21^{\text {st }}$ century by integrating hydrate stability, seafloor temperature variations, and atmospheric modeling. The mean present-day carbon reservoir within Arctic sediments is estimated to be $\sim 2524 \pm 1005$ Gt. Transient modeling of hydrate stability shows 
Earth Syst. Dynam. Discuss., https://doi.org/10.5194/esd-2017-110

Manuscript under review for journal Earth Syst. Dynam.

Discussion started: 18 December 2017

(c) Author(s) 2017. CC BY 4.0 License.

that up to $32 \pm 12$ trillion $\mathrm{m}^{3}$ of methane $(17 \pm 6 \mathrm{Gt} \mathrm{C})$ could release into the Arctic Ocean in the $21^{\text {st }}$ century as a result of warming ocean waters. However, microbial methane filter processes and oceanic conditions restrict the methane release to the atmosphere to about $1 \%$ $(0.1-10 \%)$ of the expelled methane at the seafloor. This amounts to methane emission of 2.2 $\mathrm{Tg} \mathrm{CH}_{4} \mathrm{yr}^{-1}(0.2-22)$ to the atmosphere, which results in a radiative forcing of $0.007 \mathrm{Wm}^{-2}$ (0.0007 to 0.07$) \mathrm{Wm}^{-2}$ up until 2100 . This represents less than $0.1 \%$ of the total radiative forcing in the RCP8.5 scenario, suggesting that climate impact of methane release from hydrate dissociation appears to be minor in the Arctic Ocean during the $21^{\text {st }}$ century.

\section{Data Availability}

The climate models are available from the sources mentioned in Table S1. The bottom water temperature data, heat flow data, porosity values are accessible from the websites of NOAANODC, International Heatflow Commission, and the Ocean Drilling Program respectively.

\section{Competing interests}

The authors declare that they have no conflict of interest.

\section{Acknowledgements}

This research is funded by the Research Council of Norway through the MOCA (Methane Emissions from the Arctic Ocean to the Atmosphere: Present and Future Climate Effects) project (Grant no.225814) and CAGE - Centre for Arctic Gas Hydrate, Environment, and Climate, through its Centres of Excellence funding scheme (Grant no. 223259). For their roles in producing, coordinating, and making available the CMIP5 model output, we acknowledge the climate modeling groups (Table S1), the World Climate Research Programme's (WCRP) Working Group on Coupled Modeling (WGCM), and the Global Organization for Earth 
Earth Syst. Dynam. Discuss., https://doi.org/10.5194/esd-2017-110

Manuscript under review for journal Earth Syst. Dynam.

Discussion started: 18 December 2017

(c) Author(s) 2017. CC BY 4.0 License.

by a grant from the publication fund of UiT-The Arctic University of Norway.

\section{References}

AMAPAssessment: Methane as an Arctic climate forcer. Arctic Monitoring and Assessment Programme (AMAP), Oslo, Norway, 2015.

Archer, D., Buffett, B., and Brovkin, V.: Ocean methane hydrates as a slow tipping point in the global carbon cycle, Proceedings of the National Academy of Sciences of the United States of America, 106, 20596-20601, 10.1073/pnas.0800885105, 2009.

Arora, V. K., Scinocca, J. F., Boer, G. J., Christian, J. R., Denman, K. L., Flato, G. M., Kharin, V. V., Lee, W. G., and Merryfield, W. J.: Carbon emission limits required to satisfy future representative concentration pathways of greenhouse gases, Geophysical Research Letters, 38, 10.1029/2010GL046270, 2011.

Berbesi, L. A., di Primio, R., Anka, Z., Horsfield, B., and Wilkes, H.: Methane leakage from evolving petroleum systems: Masses, rates and inferences for climate feedback, Earth and Planetary Science Letters, 387, 219-228, http://dx.doi.org/10.1016/i.eps1.2013.11.014, 2014.

Berndt, C., Feseker, T., Treude, T., Krastel, S., Liebetrau, V., Niemann, H., Bertics, V. J., Dumke, I., Dünnbier, K., Ferré, B., Graves, C., Gross, F., Hissmann, K., Hühnerbach, V., Krause, S., Lieser, K., Schauer, J., and Steinle, L.: Temporal Constraints on Hydrate-Controlled Methane Seepage off Svalbard, Science, 343, 284-287, 10.1126/science.1246298, 2014.

Biastoch, A., Treude, T., Rüpke, L. H., Riebesell, U., Roth, C., Burwicz, E. B., Park, W., Latif, M., Böning, C. W., Madec, G., and Wallmann, K.: Rising Arctic Ocean temperatures cause gas hydrate destabilization and ocean acidification, Geophysical Research Letters, 38, L08602, 10.1029/2011GL047222, 2011.

Boe, J., Hall, A., and Qu, X.: September sea-ice cover in the Arctic Ocean projected to vanish by 2100, Nature Geosci, 2, 341-343, 2009.

Buffett, B., and Archer, D.: Global inventory of methane clathrate: sensitivity to changes in the deep ocean, Earth and Planetary Science Letters, 227, 185-199, 10.1016/j.eps1.2004.09.005, 2004.

Bugge, T., Elvebakk, G., Fanavoll, S., Mangerud, G., Smelror, M., Weiss, H. M., Gjelberg, J., Kristensen, S. E., and Nilsen, K.: Shallow stratigraphic drilling applied in hydrocarbon exploration of the Nordkapp Basin, Barents Sea, Marine and Petroleum Geology, 19, 13-37, http://dx.doi.org/10.1016/S0264-8172(01)00051-4, 2002.

Burwicz, E. B., Rüpke, L. H., and Wallmann, K.: Estimation of the global amount of submarine gas hydrates formed via microbial methane formation based on numerical reaction-transport modeling and a novel parameterization of Holocene sedimentation, Geochimica et Cosmochimica Acta, 75, 45624576, http://dx.doi.org/10.1016/j.gca.2011.05.029, 2011.

Bünz, S., Polyanov, S., Vadakkepuliyambatta, S., Consolaro, C., and Mienert, J.: Active gas venting through hydrate-bearing sediments on the Vestnesa Ridge, offshore W-Svalbard, Marine Geology, 332-334, 189-197, 10.1016/j.margeo.2012.09.012, 2012.

Chabert, A., Minshull, T. A., Westbrook, G. K., Berndt, C., Thatcher, K. E., and Sarkar, S.: Characterization of a stratigraphically constrained gas hydrate system along the western continental 
Earth Syst. Dynam. Discuss., https://doi.org/10.5194/esd-2017-110

Manuscript under review for journal Earth Syst. Dynam.

Discussion started: 18 December 2017

(c) Author(s) 2017. CC BY 4.0 License.

margin of Svalbard from ocean bottom seismometer data, Journal of Geophysical Research: Solid Earth, 116, B12102, 10.1029/2011JB008211, 2011.

Ciais, P., Sabine, C., Bala, G., Bopp, L., Brovkin, V., Canadell, J., Chhabra, A., DeFries, R., Galloway, J., Heimann, M., Jones, C., Le Quéré, C., Myneni, R. B., Piao, S., and Thornton, P.: Carbon and Other Biogeochemical Cycles, in: Climate Change 2013: The Physical Science Basis. Contribution of Working Group I to the Fifth Assessment Report of the Intergovernmental Panel on Climate Change, edited by: Stocker, T. F., Qin, D., Plattner, G.-K., Tignor, M., Allen, S. K., Boschung, J., Nauels, A., Xia, Y., Bex, V., and Midgley, P. M., Cambridge University Press, Cambridge, United Kingdom and New York, NY, USA, 465-570, 2013.

Collett, T. S., Johnson, A. H., Knapp, C. C., and Boswell, R.: Natural Gas Hydrates: A Review, in: Natural gas hydrates-Energy resource potential and associated geologic hazards, edited by: Collett, T. S., Johnson, A. H., Knapp, C. C., Boswell, R., AAPG Memoir 89, 146-219, 2009.

Collins, W. J., Bellouin, N., Doutriaux-Boucher, M., Gedney, N., Halloran, P., Hinton, T., Hughes, J., Jones, C. D., Joshi, M., Liddicoat, S., Martin, G., O'Connor, F., Rae, J., Senior, C., Sitch, S., Totterdell, I., Wiltshire, A., and Woodward, S.: Development and evaluation of an Earth-System model - HadGEM2, Geosci. Model Dev., 4, 1051-1075, 10.5194/gmd-4-1051-2011, 2011.

Dalsøren, S. B., Myhre, C. L., Myhre, G., Gomez-Pelaez, A. J., Søvde, O. A., Isaksen, I. S. A., Weiss, R. F., and Harth, C. M.: Atmospheric methane evolution the last 40 years, Atmos. Chem. Phys., 16, 3099-3126, 10.5194/acp-16-3099-2016, 2016.

Damm, E., Mackensen, A., Budéus, G., Faber, E., and Hanfland, C.: Pathways of methane in seawater: Plume spreading in an Arctic shelf environment (SW-Spitsbergen), Continental Shelf Research, 25, 1453-1472, http://dx.doi.org/10.1016/j.csr.2005.03.003, 2005.

Damm, E., Schauer, U., Rudels, B., and Haas, C.: Excess of bottom-released methane in an Arctic shelf sea polynya in winter, Continental Shelf Research, 27, 1692-1701, http://dx.doi.org/10.1016/j.csr.2007.02.003, 2007.

Damm, E., Kiene, R. P., Schwarz, J., Falck, E., and Dieckmann, G.: Methane cycling in Arctic shelf water and its relationship with phytoplankton biomass and DMSP, Marine Chemistry, 109, 45-59, http://dx.doi.org/10.1016/j.marchem.2007.12.003, 2008.

Damm, V., Barckhausen, U., Behrens, T., Berglar, Ü., Ebert, T., Ehrhardt, A., Faccin, L., Gaina, C., Gricks, N., Heyde, I., Kallaus, G., Krüger, M., Schreckenberger, B., Straaten, N., Tomini, I., Visnovic, G., Zeibig, M., and Zoch, D.: BGR 13-2 PANORAMA Cruise Report, 2013.

Dickens, G. R., Castillo, M. M., and Walker, J. C. G.: A blast of gas in the latest Paleocene: Simulating first-order effects of massive dissociation of oceanic methane hydrate, Geology, 25, 259262, 10.1130/0091-7613(1997)025<0259:abogit>2.3.co;2, 1997.

Dobrynin, V. M., Korotajev, Y. P., and Plyuschev, D. V.: Gas hydrates-A possible energy resource, in: Long-term energy resources, edited by: Meyer, R. F., Olson, J. C., Pitman Publishers, Boston, 727$729,1981$.

Dufresne, J.-L., Foujols, M.-A., Denvil, S., Caubel, A., Marti, O., Aumont, O., Balkanski, Y., Bekki, S., Bellenger, H., Benshila, R., Bony, S., Bopp, L., Braconnot, P., Brockmann, P., Cadule, P., Cheruy, F., Codron, F., Cozic, A., Cugnet, D., Noblet, N., Duvel, J.-P., Ethé, C., Fairhead, L., Fichefet, T., Flavoni, S., Friedlingstein, P., Grandpeix, J.-Y., Guez, L., Guilyardi, E., Hauglustaine, D., Hourdin, F., Idelkadi, A., Ghattas, J., Joussaume, S., Kageyama, M., Krinner, G., Labetoulle, S., Lahellec, A., Lefebvre, M.-P., Lefevre, F., Levy, C., Li, Z. X., Lloyd, J., Lott, F., Madec, G., Mancip, M., Marchand, M., Masson, S., Meurdesoif, Y., Mignot, J., Musat, I., Parouty, S., Polcher, J., Rio, C., 
Earth Syst. Dynam. Discuss., https://doi.org/10.5194/esd-2017-110

Manuscript under review for journal Earth Syst. Dynam.

Discussion started: 18 December 2017

(c) Author(s) 2017. CC BY 4.0 License.

Schulz, M., Swingedouw, D., Szopa, S., Talandier, C., Terray, P., Viovy, N., and Vuichard, N.: Climate change projections using the IPSL-CM5 Earth System Model: from CMIP3 to CMIP5, Climate Dynamics, 40, 2123-2165, 10.1007/s00382-012-1636-1, 2013.

Dunne, J. P., John, J. G., Adcroft, A. J., Griffies, S. M., Hallberg, R. W., Shevliakova, E., Stouffer, R. J., Cooke, W., Dunne, K. A., Harrison, M. J., Krasting, J. P., Malyshev, S. L., Milly, P. C. D., Phillipps, P. J., Sentman, L. T., Samuels, B. L., Spelman, M. J., Winton, M., Wittenberg, A. T., and Zadeh, N.: GFDL's ESM2 Global Coupled Climate-Carbon Earth System Models. Part I: Physical Formulation and Baseline Simulation Characteristics, Journal of Climate, 25, 6646-6665, 10.1175/JCLI-D-11-00560.1, 2012.

Dunne, J. P., John, J. G., Shevliakova, E., Stouffer, R. J., Krasting, J. P., Malyshev, S. L., Milly, P. C. D., Sentman, L. T., Adcroft, A. J., Cooke, W., Dunne, K. A., Griffies, S. M., Hallberg, R. W., Harrison, M. J., Levy, H., Wittenberg, A. T., Phillips, P. J., and Zadeh, N.: GFDL's ESM2 Global Coupled Climate-Carbon Earth System Models. Part II: Carbon System Formulation and Baseline Simulation Characteristics*, Journal of Climate, 26, 2247-2267, 10.1175/JCLI-D-12-00150.1, 2013.

Etminan, M., Myhre, G., Highwood, E. J., and Shine, K. P.: Radiative forcing of carbon dioxide, methane, and nitrous oxide: A significant revision of the methane radiative forcing, Geophysical Research Letters, 43, 12614-12623, 10.1002/2016GL071930, 2016.

Ferré, B., Mienert, J., and Feseker, T.: Ocean temperature variability for the past 60 years on the Norwegian-Svalbard margin influences gas hydrate stability on human time scales, Journal of Geophysical Research, 117, C10017, 10.1029/2012jc008300, 2012.

Flato, G., Marotzke, J., Abiodun, B., Braconnot, P., Chou, S. C., Collins, W., Cox, P., Driouech, F., Emori, S., Eyring, V., Forest, C., Gleckler, P., Guilyardi, E., Jakob, C., Kattsov, V., Reason, C., and Rummukainen, M.: Evaluation of Climate Models, in: Climate Change 2013: The Physical Science Basis. Contribution of Working Group I to the Fifth Assessment Report of the Intergovernmental Panel on Climate Change, edited by: Stocker, T. F., Qin, D., Plattner, G.-K., Tignor, M., Allen, S. K., Boschung, J., Nauels, A., Xia, Y., Bex, V., and Midgley, P. M., Cambridge University Press, Cambridge, United Kingdom and New York, NY, USA, 741-866, 2013.

Gent, P. R., Danabasoglu, G., Donner, L. J., Holland, M. M., Hunke, E. C., Jayne, S. R., Lawrence, D. M., Neale, R. B., Rasch, P. J., Vertenstein, M., Worley, P. H., Yang, Z.-L., and Zhang, M.: The Community Climate System Model Version 4, Journal of Climate, 24, 4973-4991, 10.1175/2011JCLI4083.1, 2011.

Gentz, T., Damm, E., Schneider von Deimling, J., Mau, S., McGinnis, D. F., and Schlüter, M.: A water column study of methane around gas flares located at the West Spitsbergen continental margin, Continental Shelf Research, 72, 107-118, http://dx.doi.org/10.1016/i.csr.2013.07.013, 2014.

Geprägs, P., Torres, M. E., Mau, S., Kasten, S., Römer, M., and Bohrmann, G.: Carbon cycling fed by methane seepage at the shallow Cumberland Bay, South Georgia, sub-Antarctic, Geochemistry, Geophysics, Geosystems, 17, 1401-1418, 10.1002/2016GC006276, 2016.

Gerya, T.: Introduction to Numerical Geodynamic Modeling, Cambridge University Press, Cambridge, UK, 2010.

Graves, C. A., Steinle, L., Rehder, G., Niemann, H., Connelly, D. P., Lowry, D., Fisher, R. E., Stott, A. W., Sahling, H., and James, R. H.: Fluxes and fate of dissolved methane released at the seafloor at the landward limit of the gas hydrate stability zone offshore western Svalbard, Journal of Geophysical Research: Oceans, 120, 6185-6201, 10.1002/2015JC011084, 2015. 
Earth Syst. Dynam. Discuss., https://doi.org/10.5194/esd-2017-110

Manuscript under review for journal Earth Syst. Dynam.

Discussion started: 18 December 2017

(c) Author(s) 2017. CC BY 4.0 License.

Hartmann, D. L., Klein Tank, A. M. G., Rusticucci, M., Alexander, L. V., Brönnimann, S., Charabi, Y., Dentener, F. J., Dlugokencky, E. J., Easterling, D. R., Kaplan, A., Soden, B. J., Thorne, P. W., Wild, M., and Zhai, P. M.: Observations: Atmosphere and Surface, in: Climate Change 2013: The Physical Science Basis. Contribution of Working Group I to the Fifth Assessment Report of the Intergovernmental Panel on Climate Change, edited by: Stocker, T. F., Qin, D., Plattner, G.-K., Tignor, M., Allen, S. K., Boschung, J., Nauels, A., Xia, Y., Bex, V., and Midgley, P. M., Cambridge University Press, Cambridge, United Kingdom and New York, NY, USA, 159-254, 2013.

Hunter, S. J., Goldobin, D. S., Haywood, A. M., Ridgwell, A., and Rees, J. G.: Sensitivity of the global submarine hydrate inventory to scenarios of future climate change, Earth and Planetary Science Letters, 367, 105-115, http://dx.doi.org/10.1016/j.epsl.2013.02.017, 2013.

Hurrell, J. W., Holland, M. M., Gent, P. R., Ghan, S., Kay, J. E., Kushner, P. J., Lamarque, J. F., Large, W. G., Lawrence, D., Lindsay, K., Lipscomb, W. H., Long, M. C., Mahowald, N., Marsh, D. R., Neale, R. B., Rasch, P., Vavrus, S., Vertenstein, M., Bader, D., Collins, W. D., Hack, J. J., Kiehl, J., and Marshall, S.: The Community Earth System Model: A Framework for Collaborative Research, Bulletin of the American Meteorological Society, 94, 1339-1360, 10.1175/BAMS-D-12-00121.1, 2013.

Hustoft, S., Bünz, S., Mienert, J., and Chand, S.: Gas hydrate reservoir and active methane-venting province in sediments on <20 Ma young oceanic crust in the Fram Strait, offshore NW-Svalbard, Earth and Planetary Science Letters, 284, 12-24, 10.1016/j.eps1.2009.03.038, 2009.

Isaksen, I. S. A., Gauss, M., Myhre, G., Walter Anthony, K. M., and Ruppel, C.: Strong atmospheric chemistry feedback to climate warming from Arctic methane emissions, Global Biogeochemical Cycles, 25, GB2002, 10.1029/2010GB003845, 2011.

Jakobsson, M., Mayer, L., Coakley, B., Dowdeswell, J. A., Forbes, S., Fridman, B., Hodnesdal, H., Noormets, R., Pedersen, R., Rebesco, M., Schenke, H. W., Zarayskaya, Y., Accettella, D., Armstrong, A., Anderson, R. M., Bienhoff, P., Camerlenghi, A., Church, I., Edwards, M., Gardner, J. V., Hall, J. K., Hell, B., Hestvik, O., Kristoffersen, Y., Marcussen, C., Mohammad, R., Mosher, D., Nghiem, S. V., Pedrosa, M. T., Travaglini, P. G., and Weatherall, P.: The International Bathymetric Chart of the Arctic Ocean (IBCAO) Version 3.0, Geophysical Research Letters, 39, L12609, 10.1029/2012GL052219, 2012.

Jungclaus, J. H., Fischer, N., Haak, H., Lohmann, K., Marotzke, J., Matei, D., Mikolajewicz, U., Notz, D., and von Storch, J. S.: Characteristics of the ocean simulations in the Max Planck Institute Ocean Model (MPIOM) the ocean component of the MPI-Earth system model, Journal of Advances in Modeling Earth Systems, 5, 422-446, 10.1002/jame.20023, 2013.

Kort, E. A., Wofsy, S. C., Daube, B. C., Diao, M., Elkins, J. W., Gao, R. S., Hintsa, E. J., Hurst, D. F., Jimenez, R., Moore, F. L., Spackman, J. R., and Zondlo, M. A.: Atmospheric observations of Arctic Ocean methane emissions up to $82^{\circ}$ north, Nature Geoscience, 5, 318, 10.1038/ngeo1452

https://www.nature.com/articles/ngeo1452\#supplementary-information, 2012.

Kretschmer, K., Biastoch, A., Rüpke, L., and Burwicz, E.: Modeling the fate of methane hydrates under global warming, Global Biogeochemical Cycles, 29, 610-625, 10.1002/2014gb005011, 2015.

Kroeger, K. F., and Funnell, R. H.: Warm Eocene climate enhanced petroleum generation from Cretaceous source rocks: A potential climate feedback mechanism?, Geophysical Research Letters, 39, L04701, 10.1029/2011GL050345, 2012.

Kvenvolden, K. A.: Methane hydrate - A major reservoir of carbon in the shallow geosphere?, Chemical Geology, 71, 41-51, http://dx.doi.org/10.1016/0009-2541(88)90104-0, 1988. 
Earth Syst. Dynam. Discuss., https://doi.org/10.5194/esd-2017-110

Manuscript under review for journal Earth Syst. Dynam.

Discussion started: 18 December 2017

(c) Author(s) 2017. CC BY 4.0 License.

Kvenvolden, K. A., Lorenson, T. D., and Reeburgh, W. S.: Attention turns to naturally occurring methane seepage, Eos, Transactions American Geophysical Union, 82, 457-457, 10.1029/01EO00275, 2001.

Lammers, S., Suess, E., and Hovland, M.: A large methane plume east of Bear Island (Barents Sea): implications for the marine methane cycle, Geol Rundsch, 84, 59-66, 10.1007/BF00192242, 1995.

Laske, G., and Masters, G.: A Global Digital Map of Sediment Thickness, EOS Transactions, 78, F483, 1997.

Lorenson, T. D., and Collett, T.: GAS CONTENT AND COMPOSITION OF GAS HYDRATE FROM SEDIMENTS OF THE SOUTHEASTERN NORTH AMERICAN CONTINENTAL MARGIN, in: Proceedings of the Ocean Drilling Program, Scientific Results, edited by: Paull, C. K., Matsumoto, R., Wallace, P. J., and Dillon, W. P., Ocean Drilling Program, College Station, Texas, 2000.

Marín-Moreno, H., Giustiniani, M., and Tinivella, U.: The potential response of the hydrate reservoir in the South Shetland Margin, Antarctic Peninsula, to ocean warming over the 21st century, Polar Research, 10.3402/polar.v34.27443, 2015.

Marín-Moreno, H., Giustiniani, M., Tinivella, U., and Piñero, E.: The challenges of quantifying the carbon stored in Arctic marine gas hydrate, Marine and Petroleum Geology, 71, 76-82, http://dx.doi.org/10.1016/j.marpetgeo.2015.11.014, 2016.

Martin, G. M., Bellouin, N., Collins, W. J., Culverwell, I. D., Halloran, P. R., Hardiman, S. C., Hinton, T. J., Jones, C. D., McDonald, R. E., McLaren, A. J., O'Connor, F. M., Roberts, M. J., Rodriguez, J. M., Woodward, S., Best, M. J., Brooks, M. E., Brown, A. R., Butchart, N., Dearden, C., Derbyshire, S. H., Dharssi, I., Doutriaux-Boucher, M., Edwards, J. M., Falloon, P. D., Gedney, N., Gray, L. J., Hewitt, H. T., Hobson, M., Huddleston, M. R., Hughes, J., Ineson, S., Ingram, W. J., James, P. M., Johns, T. C., Johnson, C. E., Jones, A., Jones, C. P., Joshi, M. M., Keen, A. B., Liddicoat, S., Lock, A. P., Maidens, A. V., Manners, J. C., Milton, S. F., Rae, J. G. L., Ridley, J. K., Sellar, A., Senior, C. A., Totterdell, I. J., Verhoef, A., Vidale, P. L., and Wiltshire, A.: The HadGEM2 family of Met Office Unified Model climate configurations, Geosci. Model Dev., 4, 723-757, 10.5194/gmd-4-723-2011, 2011.

Mau, S., Blees, J., Helmke, E., Niemann, H., and Damm, E.: Vertical distribution of methane oxidation and methanotrophic response to elevated methane concentrations in stratified waters of the Arctic fjord Storfjorden (Svalbard, Norway), Biogeosciences, 10, 6267-6278, 10.5194/bg-10-62672013, 2013.

Mau, S., Gentz, T., Körber, J. H., Torres, M. E., Römer, M., Sahling, H., Wintersteller, P., Martinez, R., Schlüter, M., and Helmke, E.: Seasonal methane accumulation and release from a gas emission site in the central North Sea, Biogeosciences, 12, 5261-5276, 10.5194/bg-12-5261-2015, 2015.

McGinnis, D. F., Greinert, J., Artemov, Y., Beaubien, S. E., and Wüest, A.: Fate of rising methane bubbles in stratified waters: How much methane reaches the atmosphere?, Journal of Geophysical Research, 111, C09007, 10.1029/2005jc003183, 2006.

Milkov, A. V.: Global estimates of hydrate-bound gas in marine sediments: how much is really out there?, Earth-Science Reviews, 66, 183-197, http://dx.doi.org/10.1016/j.earscirev.2003.11.002, 2004

Myhre, C. L., Ferré, B., Platt, S. M., Silyakova, A., Hermansen, O., Allen, G., Pisso, I., Schmidbauer, N., Stohl, A., Pitt, J., Jansson, P., Greinert, J., Percival, C., Fjaeraa, A. M., O'Shea, S. J., Gallagher, M., Le Breton, M., Bower, K. N., Bauguitte, S. J. B., Dalsøren, S., Vadakkepuliyambatta, S., Fisher, R. E., Nisbet, E. G., Lowry, D., Myhre, G., Pyle, J. A., Cain, M., and Mienert, J.: Extensive release of 
Earth Syst. Dynam. Discuss., https://doi.org/10.5194/esd-2017-110

Manuscript under review for journal Earth Syst. Dynam.

Discussion started: 18 December 2017

(c) Author(s) 2017. CC BY 4.0 License.

methane from Arctic seabed west of Svalbard during summer 2014 does not influence the atmosphere, Geophysical Research Letters, 43, 4624-4631, 10.1002/2016GL068999, 2016.

Myhre, G., Highwood, E. J., Shine, K. P., and Stordal, F.: New estimates of radiative forcing due to well mixed greenhouse gases, Geophysical Research Letters, 25, 2715-2718, 10.1029/98GL01908, 1998.

Myhre, G., Shindell, D., Bréon, F.-M., Collins, W., Fuglestvedt, J., Huang, J., Koch, D., Lamarque, J.F., Lee, D., Mendoza, B., Nakajima, T., Robock, A., Stephens, G., Takemura, T., and Zhang, H.: Anthropogenic and Natural Radiative Forcing, in: Climate Change 2013: The Physical Science Basis. Contribution of Working Group I to the Fifth Assessment Report of the Intergovernmental Panel on Climate Change, edited by: Stocker, T. F., Qin, D., Plattner, G.-K., Tignor, M., Allen, S. K., Boschung, J., Nauels, A., Xia, Y., Bex, V., and Midgley, P. M., Cambridge University Press, Cambridge, United Kingdom and New York, NY, USA, 659-740, 2013.

Paull, C. K., Ussler, W., Dallimore, S. R., Blasco, S. M., Lorenson, T. D., Melling, H., Medioli, B. E., Nixon, F. M., and McLaughlin, F. A.: Origin of pingo-like features on the Beaufort Sea shelf and their possible relationship to decomposing methane gas hydrates, Geophysical Research Letters, 34, L01603, 10.1029/2006GL027977, 2007.

Phrampus, B. J., and Hornbach, M. J.: Recent changes to the Gulf Stream causing widespread gas hydrate destabilization, Nature, 490, 527-530, http://www.nature.com/nature/journal/v490/n7421/abs/nature11528.html\#supplementary-information, 2012.

Phrampus, B. J., Hornbach, M. J., Ruppel, C. D., and Hart, P. E.: Widespread gas hydrate instability on the upper U.S. Beaufort margin, Journal of Geophysical Research: Solid Earth, 2014JB011290, 10.1002/2014JB011290, 2014.

Pollack, H. N., Hurter, S. J., and Johnson, J. R.: Heat flow from the Earth's interior: Analysis of the global data set, Reviews of Geophysics, 31, 267-280, 10.1029/93RG01249, 1993.

Portnov, A., Smith, A. J., Mienert, J., Cherkashov, G., Rekant, P., Semenov, P., Serov, P., and Vanshtein, B.: Offshore permafrost decay and massive seabed methane escape in water depths $>20 \mathrm{~m}$ at the South Kara Sea shelf, Geophysical Research Letters, 40, 3962-3967, 10.1002/grl.50735, 2013.

Portnov, A., Vadakkepuliyambatta, S., Mienert, J., and Hubbard, A.: Ice-sheet-driven methane storage and release in the Arctic, Nat Commun, 7, 10.1038/ncomms10314, 2016.

Riahi, K., Rao, S., Krey, V., Cho, C., Chirkov, V., Fischer, G., Kindermann, G., Nakicenovic, N., and Rafaj, P.: RCP 8.5-A scenario of comparatively high greenhouse gas emissions, Climatic Change, 109, 33-57, 10.1007/s10584-011-0149-y, 2011.

Riedel, M., Novosel, I., Spence, G. D., Hyndman, R. D., Chapman, R. N., Solem, R. C., and Lewis, T.: Geophysical and geochemical signatures associated with gas hydrate-related venting in the northern Cascadia margin, Geol Soc Am Bull, 118, 23-38, 10.1130/b25720.1, 2006.

Romanovskii, N. N., Hubberten, H. W., Gavrilov, A. V., Eliseeva, A. A., and Tipenko, G. S.: Offshore permafrost and gas hydrate stability zone on the shelf of East Siberian Seas, Geo-Marine Letters, 25, 167-182, 10.1007/s00367-004-0198-6, 2005.

Ruppel, C.: Permafrost-Associated Gas Hydrate: Is It Really Approximately $1 \%$ of the Global System?, Journal of Chemical \& Engineering Data, 60, 429-436, 10.1021/je500770m, 2015.

Ruppel, C. D., and Kessler, J. D.: The interaction of climate change and methane hydrates, Reviews of Geophysics, 55, 126-168, 10.1002/2016RG000534, 2017. 
Earth Syst. Dynam. Discuss., https://doi.org/10.5194/esd-2017-110

Manuscript under review for journal Earth Syst. Dynam.

Discussion started: 18 December 2017

(c) Author(s) 2017. CC BY 4.0 License.

Sahling, H., Römer, M., Pape, T., Bergès, B., dos Santos Fereirra, C., Boelmann, J., Geprägs, P., Tomczyk, M., Nowald, N., Dimmler, W., Schroedter, L., Glockzin, M., and Bohrmann, G.: Gas emissions at the continental margin west of Svalbard: mapping, sampling, and quantification, Biogeosciences, 11, 6029-6046, 10.5194/bg-11-6029-2014, 2014.

Samset, B. H., Myhre, G., Forster, P. M., Hodnebrog, Ø., Andrews, T., Faluvegi, G., Fläschner, D., Kasoar, M., Kharin, V., Kirkevåg, A., Lamarque, J. F., Olivié, D., Richardson, T., Shindell, D., Shine, K. P., Takemura, T., and Voulgarakis, A.: Fast and slow precipitation responses to individual climate forcers: A PDRMIP multimodel study, Geophys. Res. Lett., 43, 2782-2791, 10.1002/2016GL068064, 2016.

Saunois, M., Bousquet, P., Poulter, B., Peregon, A., Ciais, P., Canadell, J. G., Dlugokencky, E. J., Etiope, G., Bastviken, D., Houweling, S., Janssens-Maenhout, G., Tubiello, F. N., Castaldi, S., Jackson, R. B., Alexe, M., Arora, V. K., Beerling, D. J., Bergamaschi, P., Blake, D. R., Brailsford, G., Brovkin, V., Bruhwiler, L., Crevoisier, C., Crill, P., Curry, C., Frankenberg, C., Gedney, N., HöglundIsaksson, L., Ishizawa, M., Ito, A., Joos, F., Kim, H. S., Kleinen, T., Krummel, P., Lamarque, J. F., Langenfelds, R., Locatelli, R., Machida, T., Maksyutov, S., McDonald, K. C., Marshall, J., Melton, J. R., Morino, I., O'Doherty, S., Parmentier, F. J. W., Patra, P. K., Peng, C., Peng, S., Peters, G. P., Pison, I., Prigent, C., Prinn, R., Ramonet, M., Riley, W. J., Saito, M., Schroder, R., Simpson, I. J., Spahni, R., Steele, P., Takizawa, A., Thorton, B. F., Tian, H., Tohjima, Y., Viovy, N., Voulgarakis, A., van Weele, M., van der Werf, G., Weiss, R., Wiedinmyer, C., Wilton, D. J., Wiltshire, A., Worthy, D., Wunch, D. B., Xu, X., Yoshida, Y., Zhang, B., Zhang, Z., and Zhu, Q.: The Global Methane Budget: 2000-2012, Earth Syst. Sci. Data Discuss., 2016, 1-79, 10.5194/essd-2016-25, 2016.

Schmidt, G. A., Ruedy, R., Hansen, J. E., Aleinov, I., Bell, N., Bauer, M., Bauer, S., Cairns, B., Canuto, V., Cheng, Y., Del Genio, A., Faluvegi, G., Friend, A. D., Hall, T. M., Hu, Y., Kelley, M., Kiang, N. Y., Koch, D., Lacis, A. A., Lerner, J., Lo, K. K., Miller, R. L., Nazarenko, L., Oinas, V., Perlwitz, J., Perlwitz, J., Rind, D., Romanou, A., Russell, G. L., Sato, M., Shindell, D. T., Stone, P. H., Sun, S., Tausnev, N., Thresher, D., and Yao, M.-S.: Present-Day Atmospheric Simulations Using GISS ModelE: Comparison to In Situ, Satellite, and Reanalysis Data, Journal of Climate, 19, 153-192, 10.1175/JCLI3612.1, 2006.

Schmidt, G. A., Kelley, M., Nazarenko, L., Ruedy, R., Russell, G. L., Aleinov, I., Bauer, M., Bauer, S. E., Bhat, M. K., Bleck, R., Canuto, V., Chen, Y.-H., Cheng, Y., Clune, T. L., Del Genio, A., de Fainchtein, R., Faluvegi, G., Hansen, J. E., Healy, R. J., Kiang, N. Y., Koch, D., Lacis, A. A., LeGrande, A. N., Lerner, J., Lo, K. K., Matthews, E. E., Menon, S., Miller, R. L., Oinas, V., Oloso, A. O., Perlwitz, J. P., Puma, M. J., Putman, W. M., Rind, D., Romanou, A., Sato, M., Shindell, D. T., Sun, S., Syed, R. A., Tausnev, N., Tsigaridis, K., Unger, N., Voulgarakis, A., Yao, M.-S., and Zhang, J.: Configuration and assessment of the GISS ModelE2 contributions to the CMIP5 archive, Journal of Advances in Modeling Earth Systems, 6, 141-184, 10.1002/2013MS000265, 2014.

Schneider von Deimling, J., Rehder, G., Greinert, J., McGinnnis, D. F., Boetius, A., and Linke, P.: Quantification of seep-related methane gas emissions at Tommeliten, North Sea, Continental Shelf Research, 31, 867-878, http://dx.doi.org/10.1016/j.csr.2011.02.012, 2011.

Screen, J. A., and Simmonds, I.: The central role of diminishing sea ice in recent Arctic temperature amplification, Nature, 464, 1334-1337, http://www.nature.com/nature/journal/v464/n7293/suppinfo/nature09051_S1.html, 2010.

Shakhova, N., Semiletov, I., Salyuk, A., Yusupov, V., Kosmach, D., and Gustafsson, Ö.: Extensive Methane Venting to the Atmosphere from Sediments of the East Siberian Arctic Shelf, Science, 327, 1246-1250, 2010. 
Earth Syst. Dynam. Discuss., https://doi.org/10.5194/esd-2017-110

Manuscript under review for journal Earth Syst. Dynam.

Discussion started: 18 December 2017

(c) Author(s) 2017. CC BY 4.0 License.

Shakhova, N., Semiletov, I., Leifer, I., Sergienko, V., Salyuk, A., Kosmach, D., Chernykh, D., Stubbs, C., Nicolsky, D., Tumskoy, V., and Gustafsson, O.: Ebullition and storm-induced methane release from the East Siberian Arctic Shelf, Nature Geosci, 7, 64-70, 10.1038/ngeo2007

http://www.nature.com/ngeo/journal/v7/n1/abs/ngeo2007.html\#supplementary-information, 2014.

Shakhova, N., Semiletov, I., Sergienko, V., Lobkovsky, L., Yusupov, V., Salyuk, A., Salomatin, A., Chernykh, D., Kosmach, D., Panteleev, G., Nicolsky, D., Samarkin, V., Joye, S., Charkin, A., Dudarev, O., Meluzov, A., and Gustafsson, O.: The East Siberian Arctic Shelf: towards further assessment of permafrost-related methane fluxes and role of sea ice, Philosophical Transactions of the Royal Society of London A: Mathematical, Physical and Engineering Sciences, 373, 10.1098/rsta.2014.0451, 2015.

Shakhova, N., Semiletov, I., Gustafsson, O., Sergienko, V., Lobkovsky, L., Dudarev, O., Tumskoy, V., Grigoriev, M., Mazurov, A., Salyuk, A., Ananiev, R., Koshurnikov, A., Kosmach, D., Charkin, A., Dmitrevsky, N., Karnaukh, V., Gunar, A., Meluzov, A., and Chernykh, D.: Current rates and mechanisms of subsea permafrost degradation in the East Siberian Arctic Shelf, 8, 15872, $10.1038 /$ ncomms 15872

https://www.nature.com/articles/ncomms15872\#supplementary-information, 2017.

Sloan, E. D., and Koh, C. A.: Clathrate Hydrates of Natural Gases, Third Edition, CRC Press, Boca Raton, FL, 752 pp., 2008.

Steinle, L., Graves, C. A., Treude, T., Ferre, B., Biastoch, A., Bussmann, I., Berndt, C., Krastel, S., James, R. H., Behrens, E., Boning, C. W., Greinert, J., Sapart, C.-J., Scheinert, M., Sommer, S., Lehmann, M. F., and Niemann, H.: Water column methanotrophy controlled by a rapid oceanographic switch, Nature Geosci, 8, 378-382, 10.1038/ngeo2420

http://www.nature.com/ngeo/journal/v8/n5/abs/ngeo2420.html\#supplementary-information, 2015.

Stevens, B., Giorgetta, M., Esch, M., Mauritsen, T., Crueger, T., Rast, S., Salzmann, M., Schmidt, H., Bader, J., Block, K., Brokopf, R., Fast, I., Kinne, S., Kornblueh, L., Lohmann, U., Pincus, R., Reichler, T., and Roeckner, E.: Atmospheric component of the MPI-M Earth System Model: ECHAM6, Journal of Advances in Modeling Earth Systems, 5, 146-172, 10.1002/jame.20015, 2013.

Stocker, T. F., Qin, D., Plattner, G.-K., Tignor, M., Allen, S. K., Boschung, J., Nauels, A., Xia, Y., Bex, V., and Midgley, P. M.: Climate Change 2013: The Physical Science Basis. Contribution of Working Group I to the Fifth Assessment Report of the Intergovernmental Panel on Climate Change, Cambridge University Press, Cambridge, United Kingdom and New York, NY, USA, 1535 pp., 2013.

Stranne, C., O'Regan, M., Dickens, G. R., Crill, P., Miller, C., Preto, P., and Jakobsson, M.: Dynamic simulations of potential methane release from East Siberian continental slope sediments, Geochemistry, Geophysics, Geosystems, 17, 872-886, 10.1002/2015GC006119, 2016a.

Stranne, C., O'Regan, M., and Jakobsson, M.: Overestimating climate warming-induced methane gas escape from the seafloor by neglecting multiphase flow dynamics, Geophysical Research Letters, 43, 8703-8712, 10.1002/2016GL070049, 2016b.

Søvde, O. A., Prather, M. J., Isaksen, I. S. A., Berntsen, T. K., Stordal, F., Zhu, X., Holmes, C. D., and Hsu, J.: The chemical transport model Oslo CTM3, Geosci. Model Dev., 5, 1441-1469, 10.5194/gmd5-1441-2012, 2012.

Takahashi, T., Sutherland, S. C., Wanninkhof, R., Sweeney, C., Feely, R. A., Chipman, D. W., Hales, B., Friederich, G., Chavez, F., Sabine, C., Watson, A., Bakker, D. C. E., Schuster, U., Metzl, N., Yoshikawa-Inoue, H., Ishii, M., Midorikawa, T., Nojiri, Y., Körtzinger, A., Steinhoff, T., Hoppema, 
Earth Syst. Dynam. Discuss., https://doi.org/10.5194/esd-2017-110

Manuscript under review for journal Earth Syst. Dynam.

Discussion started: 18 December 2017

(c) Author(s) 2017. CC BY 4.0 License.

M., Olafsson, J., Arnarson, T. S., Tilbrook, B., Johannessen, T., Olsen, A., Bellerby, R., Wong, C. S., Delille, B., Bates, N. R., and de Baar, H. J. W.: Climatological mean and decadal change in surface ocean pCO2, and net sea-air CO2 flux over the global oceans, Deep Sea Research Part II: Topical Studies in Oceanography, 56, 554-577, https://doi.org/10.1016/j.dsr2.2008.12.009, 2009.

Taylor, K. E., Stouffer, R. J., and Meehl, G. A.: An Overview of CMIP5 and the Experiment Design, Bulletin of the American Meteorological Society, 93, 485-498, 10.1175/BAMS-D-11-00094.1, 2012

Turcotte, D. L., and Schubert, G.: Geodynamics, Cambridge University Press, New York, USA, 2002.

Valentine, D. L., Blanton, D. C., Reeburgh, W. S., and Kastner, M.: Water column methane oxidation adjacent to an area of active hydrate dissociation, Eel river Basin, Geochimica et Cosmochimica Acta, 65, 2633-2640, http://dx.doi.org/10.1016/S0016-7037(01)00625-1, 2001.

von Salzen, K., Scinocca, J. F., McFarlane, N. A., Li, J., Cole, J. N. S., Plummer, D., Verseghy, D., Reader, M. C., Ma, X., Lazare, M., and Solheim, L.: The Canadian Fourth Generation Atmospheric Global Climate Model (CanAM4). Part I: Representation of Physical Processes, Atmosphere-Ocean, 51, 104-125, 10.1080/07055900.2012.755610, 2013.

Watanabe, M., Chikira, M., Imada, Y., and Kimoto, M.: Convective Control of ENSO Simulated in MIROC, Journal of Climate, 24, 543-562, 10.1175/2010JCLI3878.1, 2011.

Westbrook, G. K., Chand, S., Rossi, G., Long, C., Bünz, S., Camerlenghi, A., Carcione, J. M., Dean, S., Foucher, J. P., Flueh, E., Gei, D., Haacke, R. R., Madrussani, G., Mienert, J., Minshull, T. A., Nouzé, H., Peacock, S., Reston, T. J., Vanneste, M., and Zillmer, M.: Estimation of gas hydrate concentration from multi-component seismic data at sites on the continental margins of NW Svalbard and the Storegga region of Norway, Marine and Petroleum Geology, 25, 744-758, 10.1016/j.marpetgeo.2008.02.003, 2008.

Westbrook, G. K., Thatcher, K. E., Rohling, E. J., Piotrowski, A. M., Pälike, H., Osborne, A. H., Nisbet, E. G., Minshull, T. A., Lanoisellé, M., James, R. H., Hühnerbach, V., Green, D., Fisher, R. E., Crocker, A. J., Chabert, A., Bolton, C., Beszczynska-Möller, A., Berndt, C., and Aquilina, A.: Escape of methane gas from the seabed along the West Spitsbergen continental margin, Geophysical Research Letters, 36, L15608, 10.1029/2009g1039191, 2009.

8 
Earth Syst. Dynam. Discuss., https://doi.org/10.5194/esd-2017-110

Manuscript under review for journal Earth Syst. Dynam.

Discussion started: 18 December 2017

(c) Author(s) 2017. CC BY 4.0 License.

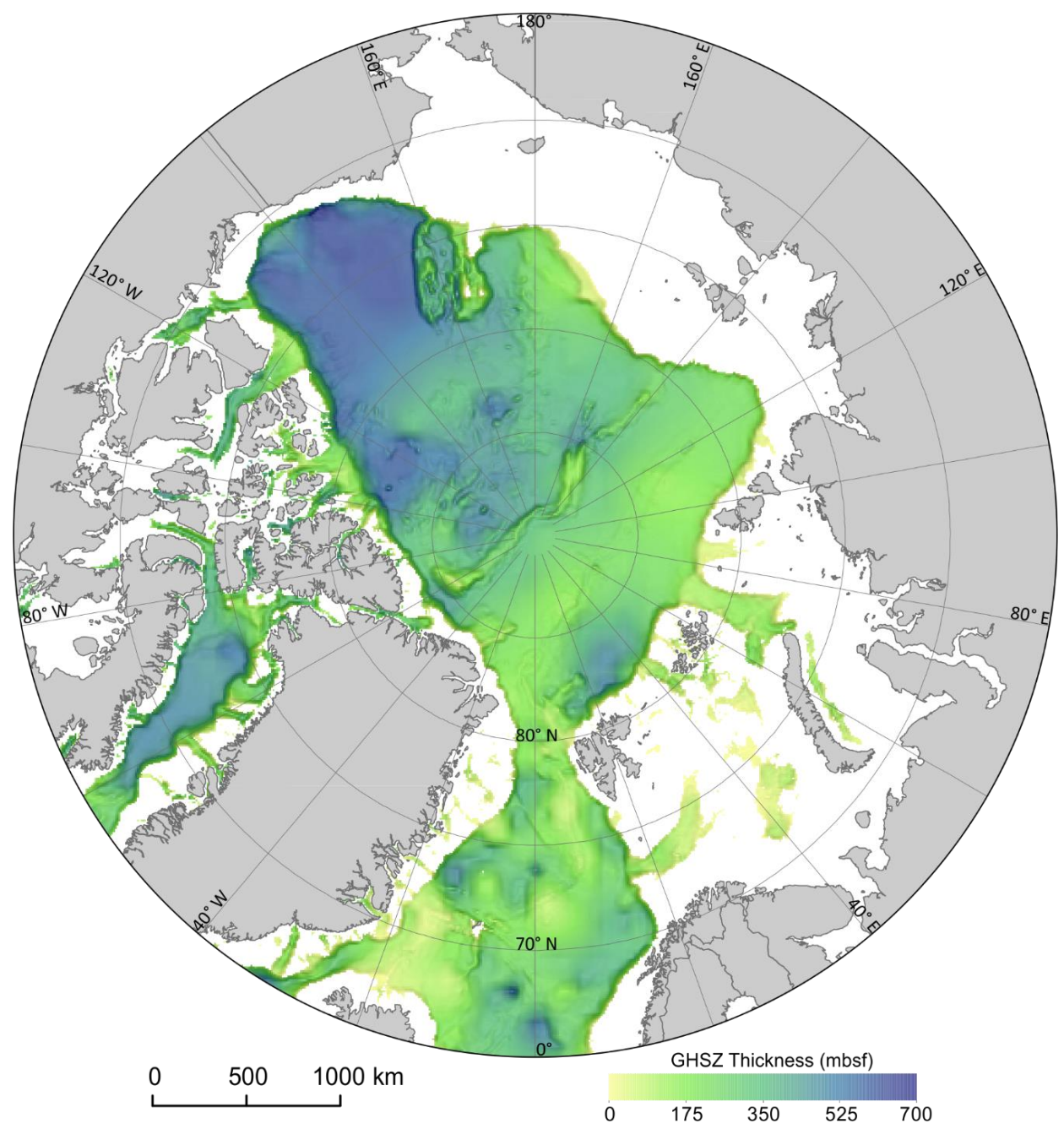

Figure 1. Present-day gas hydrate stability zone over the Arctic region modeled in this study (see supplementary S1 for details). 
Earth Syst. Dynam. Discuss., https://doi.org/10.5194/esd-2017-110

Manuscript under review for journal Earth Syst. Dynam.

Discussion started: 18 December 2017

(c) Author(s) 2017. CC BY 4.0 License.
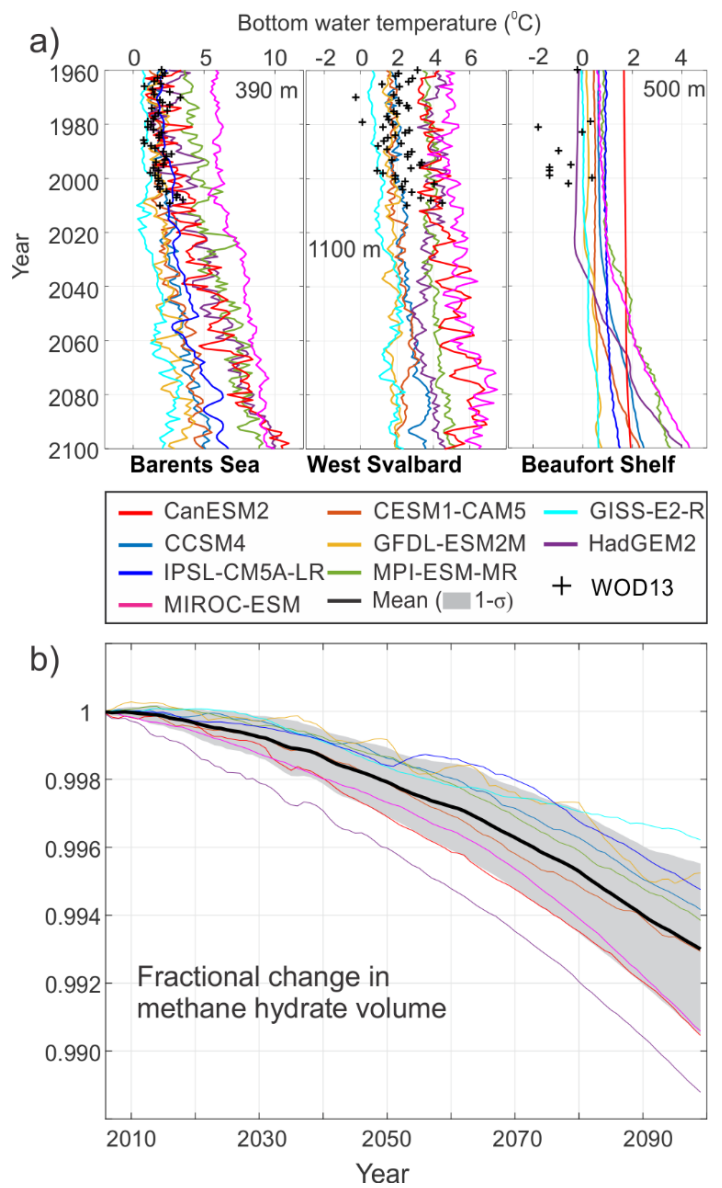

Figure 2. a) Comparison between temperature predictions from 9 CMIP5 models and measurements of bottom water temperature from high-resolution CTD (Conductivity, Depth, Temperature) data shown as black ‘+' symbols (See S1 and S3 for more details). The measured water depth is indicated in meters. b) Variation in the potential volume of methane hydrates within the hydrate stability zone with the changes in ocean bottom temperatures based on multiple climate models until the year 2100 . 
Earth Syst. Dynam. Discuss., https://doi.org/10.5194/esd-2017-110

Manuscript under review for journal Earth Syst. Dynam.

Discussion started: 18 December 2017

(c) Author(s) 2017. CC BY 4.0 License.

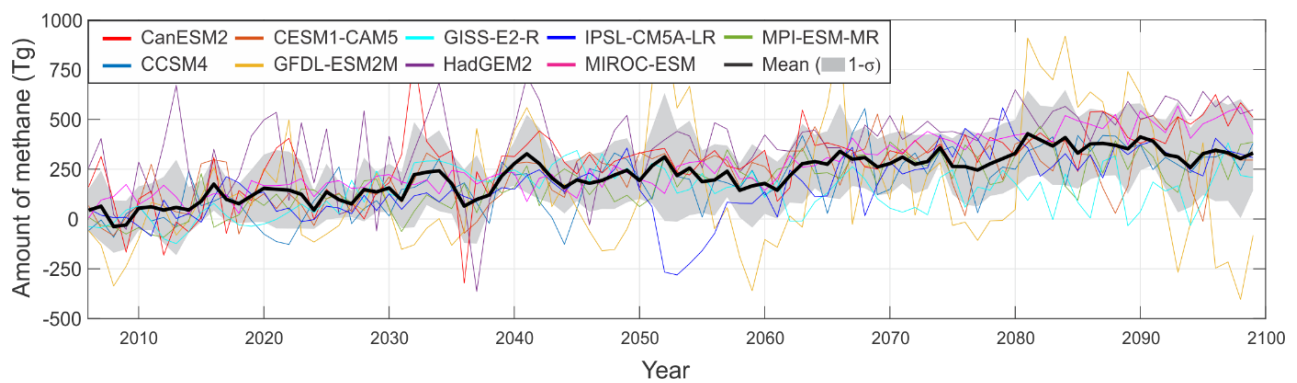

738

Figure 3. Amount of methane ( $\mathrm{Tg})$ released per year from methane hydrates to the ocean over the whole Arctic for each climate model. The mean represents the average amount of methane released each year as predicted by the nine different modeling scenarios. The shaded area represents the standard deviation (1-sigma) for each year. 
Earth Syst. Dynam. Discuss., https://doi.org/10.5194/esd-2017-110

Manuscript under review for journal Earth Syst. Dynam.

Discussion started: 18 December 2017

(c) Author(s) 2017. CC BY 4.0 License.

a)

a)
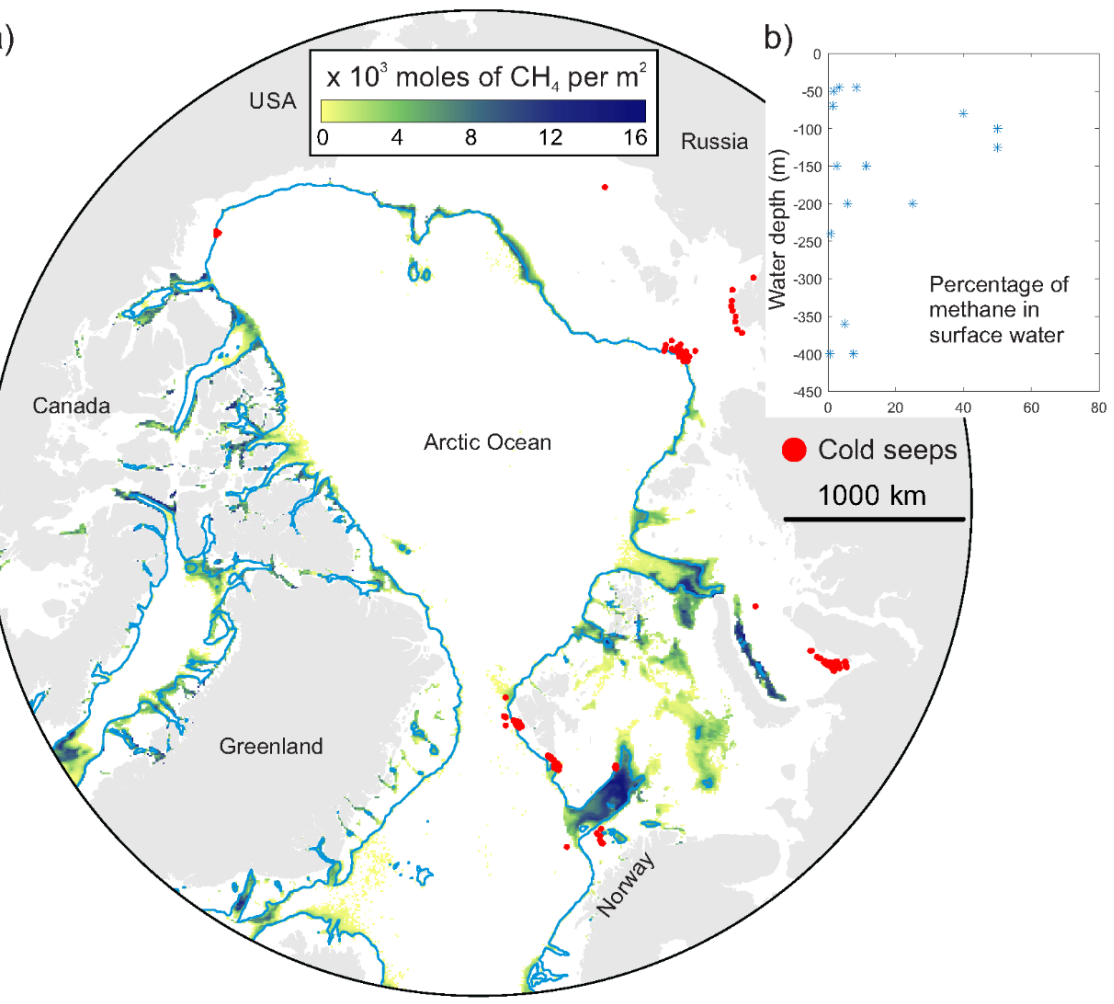

Figure 4. a) Map showing the regions and mean value of total amount of methane released until 2100. Identified methane seeps in the Arctic are also marked. The light-blue line denotes $360 \mathrm{~m}$ isobath which we identify as the hotspot for future methane release in the Arctic. b)

Percentage of methane observed (blue stars, as a function of observed bottom water concentrations) in surface water of Arctic seep locations (See table S2 in supplementary). 